\title{
OPTIC NEUROPATHY INDUCED BY LOW DOSE OF ETHAMBUTOL: A RARE PRESENTATION
}

\author{
KRISHNA RAO ADDOOR, VUPPALAPATI NISHANT JANARDHANA RAJU*, SULATHA V BHANDARY, \\ SUDHA GIRISH MENON, AAKANKSHA GUPTA
}

Department of Ophthalmology, Kasturba Medical College, Manipal University, Manipal - 576 104, Karnataka, India.

Email: nishant.janardhan@gmail.com

Received: 08 January 2017, Revised and Accepted: 24 January 2017

ABSTRACT

Ethambutol is a bacteriostatic antimicrobial agent used in the treatment of tuberculosis. Optic neuropathy is a potentially severe side effect of ethambutol, which is dose related. Ethambutol-induced optic neuropathy (EON) incidence is 15\%, 5\%, and 1\% when taken at 50, 25, and 15 mg/kg/day, respectively, for 3 months. Hence, we report a case of bilateral EON in 20-year-old female after 1 month of exposure to $15 \mathrm{mg} / \mathrm{kg} / \mathrm{day}$ of ethambutol for tubercular meningitis. Ophthalmologic examination revealed bilateral ill sustained pupillary reactions and optic disc pallor. Deranged color vision test and scotomas on Goldmann perimetry in both eyes, aided in diagnosis.

Keywords: Low dose ethambutol, Optic neuropathy, Tuberculosis.

(C) 2017 The Authors. Published by Innovare Academic Sciences Pvt Ltd. This is an open access article under the CC BY license (http://creativecommons. org/licenses/by/4. 0/) DOI: http://dx.doi.org/10.22159/ajpcr.2017.v10i4.16983

\section{INTRODUCTION}

Ethambutol hydrochloride is a bacteriostatic antimicrobial agent used as a first line defense against mycobacterium tuberculosis (TB). It acts as a chelating agent that disrupts one of the metal-containing enzymes in the nucleic acid structures of mycobacteria by preventing incorporation of mycolic acid into the mycobacterial cell wall and its toxicity involves same mechanism [1]. Optic neuropathy has been well described among toxic effects of ethambutol, causing decreased visual acuity (65.4\%), abnormal visual fields (65.4\%), abnormal color vision $(61.5 \%)$, and optic disc pallor (38.5\%) [2]. This reaction is dose related and observed in $15 \%$ of patients receiving ethambutol $50 \mathrm{mg} / \mathrm{kg} /$ day, $5 \%$ of patients receiving $25 \mathrm{mg} / \mathrm{kg} /$ day, and $<1 \%$ of patients receiving a daily dose of $15 \mathrm{mg} / \mathrm{kg}$ [3]. Optic nerve involvement is a rare side effect of isoniazid (INH) [4]. We hereby report a rare case of bilateral ethambutol-induced optic neuropathy (EON) when taken at a very low dose of $15 \mathrm{mg} / \mathrm{kg} /$ day for $1 \mathrm{month}$ and whose symptoms got completely reversed on discontinuation of ethambutol.

\section{CASE REPORT}

A 20-year-old female presented with sudden diminution of vision in both eyes since 10-15 days. It started as mild blurring of vision with, inability to recognize colors properly, difficulty in reading small letters and progressed rapidly. She has been on ethambutol $15 \mathrm{mg} / \mathrm{kg} /$ day along with the other Category I anti-tubercular treatment (ATT) drugs for 2 months in view of TB meningitis with tuberculoma.

Her visual acuity was 6/60, N10 in the right eye and 6/18, N8 in the left eye. Examination of both eyes revealed ill sustained pupillary reactions with normal intraocular pressure. Color vision test with Ishihara charts was deranged in both eyes. Fundus examination revealed bilateral temporal pallor with the blurring of temporal margins and nonspecific pigmentary changes in the macular region (Fig. 1). Goldmann perimetry showed centrocecal scotoma with peripheral field constriction in both eyes.

Ethambutol was discontinued without intervening other Category I ATT drugs and supplemented with oral vitamin B1, B5, B6, and B12 along with oral steroids $(1 \mathrm{mg} / \mathrm{kg}$ ) for 2 weeks. On review 2 weeks later visual acuity improved to $6 / 6$, N6 in both eyes with a normal color vision test, fundus picture, and Goldmann perimetry.

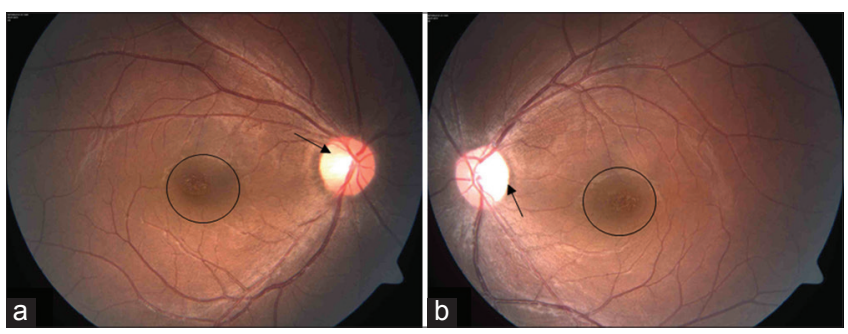

Fig. 1: Fundus photo of, (a) Right eye, (b) left eye showing temporal pallor with the blurring of temporal margins (arrow) and nonspecific pigmentary changes in the macular region (circle)

\section{DISCUSSION}

Optic neuropathy is a well-documented toxic effect of ethambutol. Although INH may also be responsible, EON is more widely recognized [5]. A survey of 37 ethambutol toxicity cases conducted by Danish Board of Adverse Reactions showed preponderance to elderly and females [6]. The occurrence of ocular toxicity is dose related, loss of vision most likely to occur in patients receiving $25 \mathrm{mg} / \mathrm{kg} /$ day or more. However, vision loss has been documented in approximately $1 \%$ of patients receiving the recommended therapeutic dose of $15-25 \mathrm{mg} / \mathrm{kg} /$ day [7]. This rarely occurs before 2 months in patients who have been on treatment, with 7 months being the average [8]. Most of the cases, vision is reversible with stoppage of ATT, rarely it is irreversible [9]. In our case report, a patient aging 20 years developed EON with very low dose of $15 \mathrm{mg} / \mathrm{kg} /$ day for the 1 month duration. With respect to above literature, EON at such a young age, with such low dosage and short duration, is very rare.

\section{CONCLUSION}

It is important for the clinicians to be aware of the rapid onset of EON even with a low dosage of ethambutol. Patients taking ethambutol should be instructed to discontinue the drug immediately at the onset of any visual symptoms and seek medical consult. All patients commencing treatment with ethambutol should have a baseline (pretreatment) ophthalmological examination. This comprises best corrected visual acuity, color vision, and visual field. These parameters 
should be monitored periodically (every 1-3 months) during the treatment period. Early detection of toxicity and withdrawal of ethambutol may be associated with good recovery.

\section{REFERENCES}

1. Kupersmith MJ, Weiss PA, Carr RE. The visual-evoked potential in tobacco-alcohol and nutritional amblyopia. Am J Ophthalmol 1983;95(3):307-14.

2. Lee EJ, Kim SJ, Choung HK, Kim JH, Yu YS. Incidence and clinical features of ethambutol-induced optic neuropathy in Korea. J Neuroophthalmol 2008;28(4):269-77.

3. Hardman JG, Limbird LE, Molinoff PB, Ruddon RW, Goodman AG. Goodman and Gilmans The Pharmacological Basis of Therapeutics. $9^{\text {th }}$ ed. New York: McGraw-Hill; 1996.
4. Kulkarni HS, Keskar VS, Bavdekar SB, Gabhale Y. Bilateral optic neuritis due to isoniazid (INH). Indian Pediatr 2010;47(6):533-5.

5. Lim SA. Ethambutol-associated optic neuropathy. Ann Acad Med Singapore 2006;35(4):274-8

6. Fledelius HC, Petrera JE, Skjødt K, Trojaborg W. Ocular ethambutol toxicity. A case report with electrophysiological considerations and a review of Danish cases 1972-81. Acta Ophthalmol (Copenh) 1987;65(2):251-5.

7. Kahana LM. Toxic ocular effects of ethambutol. CMAJ 1987;137(3):213-6.

8. Polak BC, Leys M, van Lith GH. Blue-yellow colour vision changes as early symptoms of ethambutol oculotoxicity. Ophthalmologica 1985;191(4):223-6.

9. Bhandary SV, Sehgal A, Rao LG, Rao AK, Kusumgar P, Thanusubramanian H. Bilateral blindness due to anti-tubercular treatment: A rare presentation. Asian J Pharm Clin Res 2016;9(2):1-2. 